\title{
Laura Kadile
}

\section{Gribas izteikums kā tiesiska darījuma svarīgākais elements Expression of will as the most important element of legal transaction}

\begin{abstract}
To any uninvolved reader, word combinations like "understand the meaning of one's action" and "ability to control one's action" can be confusing. Would the legislator have deliberately created such a broad-ranging combination of philosophical concepts in the text of a legal norm that each factual circumstance could be covered under these concepts and render applicable the legal consequences specified in the legal norm, or, after all, does the legal doctrine and case law already envisage a clear model, according to which the respective legal norm is applied? In the absence of a uniform filling of a legal norm with substance, might such an interpretation permit a purely subjective assessment?

For a uniform interpretation and application of legal norms to exist in practice, the interpretation must be based on new fundamental principles and a common legal doctrine, abstaining from the case law and understanding of legal norms that existed before the reform of civil procedure capacity.

Keywords: expression of will, the capacity to understand one's actions or to control them, capacity to act, legal transaction.

This paper is prepared within the research project "Towards a human rights approach for mental health patients with a limited capacity: a legal, ethical and clinical perspective Izp-2020/1-0397”.
\end{abstract}

\section{levads}

Ik dienu katram no mums ir jāpieṇem kāds lēmums. Tie var būt lēmumi, kuru pieṇemšanai nav nepieciešamas padziḷinātas zināšanas kādā 
nozarē un liela prāta piepūle, piemēram, iegādājoties pārtikas produktus lielveikalā.

Tomēr bieži vien mums ir jāizšḳiras par lēmumiem, kas, tieši pretēji, prasa kādas papildu un sevišḳas zināšanas kādā noteiktā un specifiskā nozarē, ar kurām nav apveltīta ikviena vidusmēra saprātīga persona. Starp šādiem lēmumiem minama tāda tiesisko darījumu noslēgšana kā nekustamā īpašuma iegāde vai automašīnas noma. Šo darījumu noslēgšanai un līgumu sastādīšanai ir nepieciešamas speciālas zināšanas tiesību zinātnē, īpaši saistību un lietu tiesību nozarē.

Lai persona spētu, no vienas puses, godprātīgi izmantot savas tiesības, bet, no otras puses, ievērot tiesību normās imperatīvi noteiktos pienākumus, personai ir jābūt apveltītai ne vien ar noteiktām spriešanas spējām saprast tiesību normu un tiesiskā darījuma sastāvu un tā sekas, bet arī apzināties savas darbības tiesiskās un faktiskās sekas. Līdz ar to ne katram ir piešḳirtas tiesības pien,emt noteiktus lēmumus un noslēgt tiesiskos darījumus.

Šobrīd spēkā esošais tiesību normu regulējums noteic, ka tiesiskos darījumus var slēgt fiziskas un juridiskas personas, kurām ir atbilstoša tiesībspēja un rīcībspēja. Tiesībspēja ir spēja būt par civilo tiesību nesēju (subjektu), kas fiziskai personai piemīt kopš dzimšanas brǐža. Savukārt ar rīcībspēju tiek saprasta spēja ar savām darbībām iegūt tiesības un uzn,emties pienākumus. Tās priekšnoteikums ir gribas briedums, noteikts veselības stāvoklis, kā arī līdzēja saprātīga izturēšanās, kas pēc likuma iestājas līdz ar noteikta vecuma sasniegšanu.

Tomēr pat apstākḷos, kad personai piemīt likumā noteiktā tiesībspēja un rīcībspēja, var pastāvēt tādi faktiskie un fizioloǵiskie apstākḷi, kādos persona pati tādā apjomā, kādā tiesa nav ierobežojusi personas rīcībspēju, vai arī persona, kuras rīcībspējas tiesa ar spēkā stājušos tiesas spriedumu nav ierobežojusi, nespēj savu k̦ermeni ne kontrolēt, ne valdīt pār to. Tādēḷ šādos brīžos svarīgi ir jau agrīni ar speciālu testu, eksperimentu un novērojumu palīdzību konstatēt šādu personas stāvokli, nepieḷajot tiesību subjektam patstāvīgi noslēgt tiesiskos darījumus.

Nereti cilvēks, kas apzinas un gribas traucējumu dēl noslēdz tiesisku darījumu, vienlaikus ir pacients Ārstniecības likuma izpratnē, tādē| šādas personas spējas saprast savas darbības vai tās vadīt var tikt ietekmētas 
arī tad, ja tiek lietotas vai organismā ievadītas narkotiskās un psihotropās vielas. Turklāt īpaša vērība jāpievērš pacientiem, kas tiesiskos darījumus noslēdz savas dzīves nogalē, tostarp slimojot ar demenci jeb vecuma plānprātību, kas var ietekmēt tiesiska darījuma spēkā esamību.

Šì raksta mērḳis ir noskaidrot tiesiska darījuma jēdzienu, institūtu un galvenās tā sastāvdaḷas, vēršot uzmanību uz gribas izpaudumu un tā nozīmi tiesiska darījuma noslēgšanā. Tostarp vispārēji aplūkojot tos cilvēka gribas, apzinnas un psihiskos traucējumus, kas ietekmē vai var ietekmēt personas rīcībspēju (ar padziḷinātu uzsvaru uz darījumspēju), noslēdzot tiesiskus darījumus, un pētīt ǵenerālklauzulas spēja saprast savas darbības nozìmi vai to vadìt saturu, pacienta tiesiskā stāvokḷa īpatnības un tiesisko darījumu noslēgšanu ārstniecības iestādēs, analizējot pastāvošās tiesiskās problēmas, nepilnības kā nacionālo, tā arī starptautisko tiesību avotos un piedāvājot konkrētus priekšlikumus to novēršanai.

\section{Tiesiska darījuma jēdziens un gribas izpauduma nozīme tajā}

\subsection{Tiesiska darījuma institūts un tā sastāvdaḷas}

Ikvienai personai, pamatojoties uz privātautonomijas principu, ir tiesības piedalīties tiesiskajās attiecībās, kā arī izvēlēties līguma saturu un nodibināt sev tādas tiesības un pienākumus, kādus vien viṇi vēlas, ciktāl to neierobežo likuma imperatīvās normas. Savukārt tiesību normām ir jāaizsargā tās personas, kas iesaistās tiesiskās darījuma attiecībās, tomēr, n,emot vērā šo personu garīgās veselības traucējumus, tās nespēj paust savu brīvu gribas izteikumu, kas ir obligāts priekšnoteikums tiesiska darījuma noslēgšanai [Knothe 2017: § 104-115 Rn. 20]. Ir jāierobežo situācijas, kurās otrs darījuma partneris varētu izmantot šādu personas stāvokli.

Tomēr no privātautonomijas principa izrietošā personas brīvība nav absolūta, tā tiek ierobežota ar imperatīvu normu palīdzību. lerobežojumiem ir dažādi mērḳi, piemēram, kontrahenta, trešās personas, valsts, sabiedrības vai civiltiesiskās apgrozības aizsardzība. Apstākḷos, kad persona nespēj kontrolēt savu darbību nozīmi, kā arī apzināties savu darbību 
tiesiskās sekas, likumā noteiktajos gadījumos šīm personām var tikt ierobežota šì "brīvā" tiesība nodibināt jebkuras tiesiskās attiecības. Savukārt, ja tiesiskais darījums ticis noslēgts ierobežotas rīcībspējas stāvoklī attiecīgi garīga rakstura, gribas vai apzinnas traucējumu ietekmē, tas var tikt atzīts par spēkā neesošu no tā parakstīšanas brīža.

Tiesiskā darījuma institūts ir viens no būtiskākajiem instrumentiem privāto tiesību jomā, kas rada tiesiskās sekas. Ar ši institūta palīdzību tiek īstenotas juridisko un fizisko personu likumiskās mantiskās un nemantiskās intereses. Savukārt tiesisko attiecību nodibināšanas, pārgrozǐšanas vai izbeigšanas pamatā ir juridiskie fakti jeb facta, ar ko tiek saprasti jebkuri apstākḷi, kam var būt tiesiskās sekas [Гамбаров 1911: 632; Васьковский 1894: 98, 99]. Tiesisks darījums ir vissvarīgākais no visiem juridiskiem faktiem [Гамбаров 1911: 668], un tieši tajos visplašāk izpaužas privātpersonu autonomijas princips [Balodis 2007: 150]. Tādējādi juridiski fakti ir plašākā juridiskā kategorija, kas ietver arī tiesiskus darījumus.

Tiesiska darījuma institūts ir ietverts Latvijas Republikas Civillikuma ceturtās daḷas "Saistību tiesības" pirmajā nodaḷā "Tiesiski darījumi vispār". Attiecīgi Civillikuma 1403. pants ietver tiesiska darījuma definīciju (tiesisks darījums ir atlautā kārtā izdarīta darbība tiesisku attiecību nodibināšanai, pārgrozīšanai vai izbeigšanai), savukārt 1404. pants uzskaita piecus darījumam nepieciešamos elementus:

1) darījuma dalībnieki (1405.-1411. pants);

2) tiesisku darījumu priekšmets (1412.-1426. pants);

3) gribas izteikums un īstums (1427.-1468. pants);

4) tiesiska darījuma sastāvdalas (1469.-1472. pants);

5) tiesiska darījuma forma (1473.-1481. pants).

Šie pieci elementi ir ṇemami vērā katrā tiesiskā darījumā. Kāda elementa neesamība vai nepilnība attiecīgi padara konkrētu darījumu par spēkā neesošu, apstrīdamu vai tādu, kura spēkā esamību iespējams saglabāt, veicot kādas papildu darbības, kas novērš sākotnēji pieḷautos trūkumus. Šajā pētījumā autore vērsīs uzmanību tieši uz gribas izteikuma īstumu kā tiesiska darījuma elementu, kas atzīstams kā obligāta tiesiska darījuma sastāvdaḷa, bez kuras tiesisks darījums nav uzskatāms par spēkā esošu. 


\subsection{Gribas izteikuma nozīme tiesiska darījuma noslēgšanā}

Līdz pat šodienai dažādu zinātṇu pārstāvji ir centušies definēt brīvas gribas definīciju. Filozofijas zinātnē brīvas gribas definīcija līdz pat šai dienai nav skaidrota, tāpēc pakḷauta plašām diskusijām [Habermeyer/Saß 2002: 5 (7)]. Tomēr, kā tas norādīts Vācijas tiesību doktrīnā, likumdevējs, pien,emot brīvas gribas izpauduma regulējumu, visupirms vēēejjies izvairīties no gribas termina izpratnes filozofijas nozarē, jēdzienu skaidrojot tā, kā to saprastu jebkura persona ikdienišḳā sarunvalodā. Līdz ar to ikdienā ar brīvas gribas izpaudumu saprot ikvienas personas spēju pareizi uztvert pasaules uzskatus un saprātīgi izteikt savus apsvērumus. Personu uzvedības pamatā ir racionāli apsvērumi, turklāt vairāk par apsvērumu racionalitāti nekas papildus netiek prasīts [LAG Koln, Urteil vom 13.11.1998 - 11 Sa 25/98, NZA-RR 1999, s. 232 (233)].

Kā tas norādīts tiesību doktrīnā, darījums pēc savas būtības ir gribas akts, kurš izšḳir darījuma dalībnieku iekšējo gribu un šīs gribas izpausmi. Griba ir darījuma noslēgšanas pamats, kas veidojas dažādu motīvu ietekmē. Tomēr, lai noslēgtu darījumu, ar iekšējo gribu vien nepietiek. Griba noslēgt darījumu ir jādara zināma citiem [Vēbers 1979: 101], visupirms pārējiem darījuma dalībniekiem, kā arī attiecīgām iestādēm, kuru darbība saistīta ar darījumu noformēšanu. Juridiskā ziṇā nozīmīga ir tieši gribas izpausme, jo galvenokārt tā liecina par personu gribu stāties darījumā un parasti normālos apstākḷos arī pareizi atspoguḷo iekšējo gribu, atbilst tai. Tāpēc arī darījuma noslēgšanu un tā spēkā esamību likums saista tieši ar gribas izpausmi kā katra darījuma svarīgāko elementu. Līdz ar to darījums izraisa juridiskās sekas, tāpēc ka likums šīs sekas saista ar gribas izteikumu [Vēbers 1979: 101].

Atbilstoši šobrīd spēkā esošajai Civillikuma 1409. panta redakcijai [Civillikums. Valdības Vēstnesis, 41, 20.02.1937.] tiesiski darījumi, ko taisījušas rīcībspējīgas personas nesamañas stāvoklī vai nespējot saprast savas darbības nozīmi vai nespējot savu darbību vadīt, nav spēkā. Gramatiski tulkojot Civillikuma 1409. pantu, ir redzams, ka tiesību norma sastāv no trim komponentēm, no kurām ikvienā gadījumā tiesisks darījums ir atzīstams par spēkā neesošu. Attiecīgi apstākḷos, ja persona atrodas nesamaṇas stāvoklī, kā arī apstākḷos, ja personai nepiemīt noteiktās spējas 
saprast vai spējas savas darbības vadīt. Tātad, izšḳirot to, vai tiesiskais darījums ir uzskatāms par spēkā esošu, svarīgākais darījuma elements, kas ir jāizvērtē, ir līdzēja gribas izpaudums. Jāizcel, ka noteiktos apstākḷos gribas izpausme personām var būt traucēta psihopatoloǵisku, fizioloǵisku vai medicīnisku iemeslu dēḷ.

Civillikums šajā pantā nenoteic to robežu, kādam jābūt garīga rakstura traucējumam, lai tiesisku darījumu atzītu par spēkā neesošu. Tāpēc strīdu gadījumos tieši tiesas pienākums ir noteikt un izvērtēt, vai stāvoklī, kurā atradās persona, viṇa varēja adekvāti izteikt savu brīvu gribu. Turklāt Civillikuma 1409. pants nesatur nekādas atrunas par nesamañas vai garīga rakstura traucējumu cēloṇiem vai šādas nesamaṇas vai garīga rakstura traucējumu noteikšanas kārtību attiecībā uz tiesisku darījumu spēkā neesamību. Šādos apstākḷos tiesību piemērotājs nespēj ne noteikt, ne arī izvērtēt personas apziṇas stāvokli, kādā persona darījumu būtu noslēgusi.

Spēja apzināties savas rīcības nozīmi un apzināties rīcības sekas ir atšḳirīgi jēdzieni, no kuriem pirmais attiecas uz darījuma būtību, bet otrais - uz tā iespējamām sekām, kuras darījuma slēgšanas brīdī ar lielāku vai mazāku varbūtības pakāpi visos gadījumos var vienīgi prognozēt [Latvijas Republikas Augstākās tiesas 2018. gada 2. novembra spriedums lietā SKC-127/2018]. Autore uzskata, ka tiesību normas piemērošanā būtu svarīgi noskaidrot, vai līgumslēdzējs saprot un apzinās tiesiska darījuma noslēgšanu, savukārt gribas sfēra jeb spēja savas darbības vadīt var būt deformēta gan fizisku, gan garīgu veselības traucējumu dēḷ. Līdz ar to autores ieskatā, piepildot šîs ǵenerālklauzulas saturu, visupirms ir jānoskaidro, vai persona apzinās savu rīcību, spēj paredzēt savas uzvedības sekas, spēj izplānot savu uzvedību, kā arī spēj to regulēt.

\section{Apzinas un gribas traucējumu ietekme uz tiesisku darījumu noslēgšanu}

Tā kā tiesisks darījums pamatojas uz pušu gribas izteikumu, kas vērsts uz tiesisku attiecību nodibināšanu, grozǐšanu vai izbeigšanu, no tā izriet, ka darījumu spēkā neesamību nosaka vai nu viṇu pretruna ar likumu, vai arī gribas izteikuma defekti un gribas traucējumi. 
Lai tiesisku darījumu atzītu par spēkā neesošu, būtiska nozīme ir tam, vai darījuma noslēgšanas brīdī personai bijuši tādi īslaicīgi apziṇas un gribas traucējumi, ar kuriem nevar nerēḳināties [Augstākās tiesas Senāta 2011. gada 25. maija sprieduma lietā Nr. SKC-211/2011]. Lai spētu konstatēt personas apzinnas spējas noslēgt tiesisku darījumu, attiecīgi to, vai persona apzinās šāda darījuma sarežǵîtību, tā uzbūvi, tajā ietverto terminoloǵiju un juridiskās sekas, doktrīnā jau iepriekš noteikts, ka, novērtējot personas apziṇas prasmes, tiek n,emta vērā, pirmkārt, tās apziṇas pakāpe un konstatēšanas spējas, otrkārt, orientēšanās spējas, treškārt, uzmanība un koncentrēšanās spējas, ceturtkārt, atminna. Visbeidzot, novērtējot personas apziṇas spējas, tieši personas intelektuālajām spējām tiek piešḳirta liela nozīme [Werterberger 1993: 24-96].

Jāizcel, ka aplūkojamās tēmas un turpmākā pētījuma ietvaros autori interesē tieši apziṇas un gribas traucējumi, kas var piemist arī personām, kuru rīcībspēja nav tikusi ierobežota ar spēkā stājušos tiesas spriedumu vai ierobežota tik tālu, cik šādu darījumu tā ir tiesīga noslēgt, tostarp ikvienam no mums, tādēl autore sākotnēji aplūkos apziṇas un gribas traucējumu jēdzienu.

Ar terminu "traucējumi" medicīnas un psihiatrijas nozarē tiek saprastas psihiskas un psiholoǵiskas anomālijas, kas aptver jebkāda veida garīga rakstura un k̦ermeniskas izmainnas [Windbüchler 1829: 34]. Lielākoties tie ir galvas smadzeṇu bojājumi, smadzeṇu traumas vai spēcīgas endogēnās psihozes jeb smagas psihiskas slimības, kam raksturīgi tādi simptomi kā murgi, halucinācijas, kustību traucējumi u. tml. [Hoff 2015: 80]. Jēdziens "gribas traucējumi" aptver divus traucējumu veidus - pastāvīgo veǵetatīvo stāvokli (tiek dēvēts arī kā noturīgais veǵetatīvais stāvoklis) un minimālu gribas traucējumu stāvokli [Anglijas Augstākās tiesas 2018. gada 30. jūlija spriedums lietā [2018] UKSC 46]. Apziṇa un tās traucējumi attiecināmi uz katras personas individuālo sfēru, bet personas griba un tās izteikums tiek pausts uz ārieni. Salīdzinājumam: apziṇas traucējumi būtu pielīdzināmi cēlonim, savukārt gribas traucējumi - sekām. Tādēl gribas izpausmes traucējumi var izpausties lēmumā, ko persona ir pieṇēmusi apzināti, bet neatbilstoši izvēlētajam mērḳim vai arī pieṇēmusi tad, kad personas darbības atbilst izvēlētajam mērḳim, bet tās gribas izpaudums nav bijis brīvs. 


\section{Pacients kā speciālais tiesību subjekts}

Personas veselības stāvoklim strīdus darījumu parakstīšanas brīdī ir liela nozīme. Personas vēlme noslēgt tiesisko darījumu ir šīs personas apzināta rīcība, kas radusies uz brīvas gribas izpauduma pamata. Lai persona spētu izmantot savas tiesības un ievērotu zināmus pienākumus, tai ir nepieciešamas noteiktas spriešanas spējas, spēja saprast tiesību normu saturu, kā arī apzināties savu darbību ceḷā uz tiesisku darījumu noslēgšanu un šo darbību faktiskās un tiesiskās sekas.

Cilvēka spējas saprast savas darbības vai tās vadīt var samazināties slimību, traumu, narkotisku un psihotropu vielu (medikamentu) lietošanas, kā arī citu faktoru dēḷ. Tā rodas vairāk vai mazāk spēcīgi apziṇas traucējumi, cilvēks var būt dezorientēts kā laikā, tā arī telpā, tādēl cilvēka spējas saprast savu lēmumu, tostarp darījumu, tiesisko saturu un tiesiskās sekas ir ierobežotas, kā arī ir iespējams, ka šādas spējas cilvēkam faktiski nepiemīt.

Lielākoties jautājumi par personas spēju noslēgt tiesiskos darījumus (darījumspēju) rodas pēc netipisku līgumu noslēgšanas, apstākḷos, kad persona ir piedzīvojusi kādu smagu pārdzīvojumu, atradusies psihozes stāvoklī, ir tikusi saindēta vai slimojusi ar demenci. Lai noslēgtu tiesisko darījumu, no līdzēja tiek pieprasîta pilnīgāka izpratne par līguma tiesisko dabu, tā nosacījumiem un līguma tiesiskajām sekām [Mossman, Shoemaker 2010: 117-197]. Piemēram, apstākḷos, ja tiesiskajā darījumā ietvertie nosacījumi ir juridiski sarežǵīti vai ietver specifiskus juridiskus terminus, no kontrahenta puses tiek prasīts salīdzinoši augstāks darījuma satura izpratnes līmenis nekā salīdzinoši vienkāršu darījumu noslēgšana ikdienā. Līdz ar to šādas izpratnes pārbaudē jeb testā vissvarīgākās ir cilvēka kognitīvās spējas.

Pacienta kā speciālā subjekta tiesiskais stāvoklis Ārstniecības likuma izpratnē tiek skatīts plašāk nekā Civillikumā nostiprinātais rīcībspējas regulējums, aptverot ne vien apzinnas un gribas traucējumu ietekmi uz pacienta spējām saprast un vadīt savas darbības, bet arī pacienta fiziskos defektus un vispārējo veselības stāvokli kopumā, tostarp pēc spēcīgu medikamentu lietošanas ārstniecības iestādēs. Pacienta tiesisko stāvokli îslaicīgi var ietekmēt ārkārtas apstākḷi (piemēram, šoks, sāpes, 
medikamenti), tāpēc pacients var nespēt izvērtēt informāciju un pieṇemt lēmumu [Kennedy, Grubb 1998: 868].

Tādēl, novērtējot personas kognitīvās spējas noslēgt tiesisko darījumu, personai ir jāspēj uzdot noteikti jautājumi pirms šāda darījuma noslēgšanas, kas saistīti ar tiesiskā darījuma nozīmi, saturu, tā nosacījumiem un spēkā esamību, arī apstākḷos, ja persona atrodas ārstniecības iestādē. Šādos apstākḷos pienākums gulstas uz ārstu un medicīnas darbinieku pleciem.

Lai to sasniegtu, ir jāveido vienota kārtība un prakse ārstniecības iestādēs attiecībā uz lēmumu pieṇemšanas spēju noteikšanu pacientiem, kuriem ir kāda no lēmumu pieṇemšanas spēju trūkuma pazīmēm. Svarīgi, ka slimnīcās tiek īstenota prakse, kas nodrošina tiesiski korektu informētu piekrišanas iegūšanu vai tiesisko darījumu noslēgšanu gadījumos, ja pacientu lēmumu pieṇemšanas spējas ir ierobežotas.

\section{Secinājumi}

Lai īstenotu pašnoteikšanās un brīvības tiesības, cilvēkam ir jāspēj saprast savas darbības un tās vadīt tādā apjomā, lai spētu pieñemt saprātīgu lēmumu. Personu spējas pien,emt lēmumus ietekmē dažādi faktori, tāpēc ne visas personas un ne visos apstākḷos spēj pieṇemt lēmumus. Pat garīgi veseli cilvēki noteiktās dzīves situācijās var pieṇemt tādus lēmumus, kas nav uzskatāmi par racionāliem vai kas nav pieṇemti, balstoties uz tīri loǵiskiem apsvērumiem. Cilvēkiem, kuru veselību īslaicīgi vai ilglaicīgi ietekmē saslimšana vai trauma, to dēl bieži samazinās spējas saprast savas darbības vai tās vadīt un tāpēc samazinās lēmumu pieṇemšanas spējas.

Šādos apstākḷos ir īpaši svarīgi izpētīt, kas spēj uzlabot vai, tieši otrādi, pasliktināt tiesiska darījuma tiesiskā dalībnieka apziṇas stāvokli un kognitīvās spējas, nosakot vienotus pārbaudes veidus, lai noskaidrotu, vai attiecīgā persona, n,emot vērā tās veselības stāvokli, spēj saprast savu darbību nozīmi vai tās vadīt, lai nodrošinātu ikviena pacienta Satversmē noteiktās tiesības uz personas cieṇu un tiesisko aizsardzību ārstniecības procesā kopumā. 


\section{Izmantotā literatūra}

1. Anglijas Augstākās tiesas 2018. gada 30. jūlija spriedums lietā [2018] UKSC 46.

2. Balodis, K. (2007). levads civiltiesībās. Rīga: Zvaigzne ABC, 150. Ipp.

3. Civillikums. Valdības Vēstnesis, Nr. 41, 20.02.1937. Pieejams: https://likumi.lv/ ta/id/225418 (skatīts 06.10.2020.)

4. Habermeyer, E. Saß, H. (2002). Ein am Willensbegriff ausgerichteter, symptomorientierter Ansatz zur Prufung der Geschaftsfahigkeit. In: Fortschritte der Neurologie und Psychiatrie, Vol. 70 (1), s. 5-10.

5. Hoff K. (2015). Die Nichtigkeit einer Willenserklärung nach 105 Abs. 2 BGB unter Berücksichtigung medizinischer Störungen. Göttingen: Cuvillier Verlag, s. 80.

6. Kennedy, I., Grubb, A. (1998). Principles of medical law. Oxford: Oxford University Press, $868 \mathrm{p}$.

7. LAG Koln, Urteil vom 13.11.1998 - 11 Sa 25/98, NZA-RR 1999, s. 232 (233).

8. Latvijas Republikas Augstākās tiesas 2018. gada 2. novembra spriedums lietā SKC-127/2018.

9. Latvijas Republikas Augstākās tiesas Senāta 2011. gada 25. maija spriedums lietā Nr. SKC-211/2011.

10. Mossman, D., Shoemaker, A. N. (2010). Incompetence to maintain a divorce action: when breaking up is odd to do. In: St. John's Law Review, No. 84, pp. 117-197.

11. Vēbers, J. (1979). Padomju civiltiesības. Rīga: Zvaigzne, 101. Ipp.

12. von Staudinger, J. (2017). Kommentar zum Bürgerlichen Gesetzbuch mit Einführungsgesetz und Nebengesetzen, Buch 1, Allgemeiner Teil, §§ 90-124, 130-133, Neubearbeitung. Berlin: Sellier / de Gruyter, § 104-115 Rn. 20

13. Wetterberg, L. (1993). Psihiatrijas rokasgrāmata. Zviedrija, 24.-96. Ipp.

14. Windbüchler G. J. (1829). Vesuch einer Diagnose un Atiologie der psychischen Krankheiten. Wien: Druck und Verlag der Mechitaristen Congregations Buchhandlung, s. 34.

15. Васьковский, Е. В. (1894). Учебник гражданского права. Выпуск 1. Введение и общая часть. СПб.: издание Юридического Книжного Магазина Н. К. Мартынова, с. 98, 99, 668.

16. Гамбаров, Ю. С. (1911). Курс гражданского права. Том І. Часть общая. С.-Петербург: типография М. М. Стасюлевича, с. 632. 